\title{
Perubahan Pola Parkir Akibat Penambahan Fungsi Bangunan di Kawasan Paskal Hypersquare di Kota Bandung
}

\author{
Dewi Parliana $^{1}$, Amakarelia Tandi Seru Matasak ${ }^{1}$, Ervine Novarizka Hardjiyantie ${ }^{1}$, \\ Annisa Rahma Syarifah ${ }^{1}$ \\ ${ }^{1}$ Program Studi Arsitektur - Fakultas Arsitektur dan Desain \\ Itenas, Institut Teknologi Nasional Bandung \\ Email: dpar@itenas.ac.id
}

\begin{abstract}
ABSTRAK
Perubahan tatanan fungsi dan massa bangunan yang diakibatkan oleh perluasan pada sebuah kawasan kota akan mengakibatkan perubahan pada fungsi lainnya, diantaranya fungsi parkir. Penelitian ini akan mengkaji mengenai perubahan kawasan Paskal 23 di Kota Bandung Indonesia yang berkaitan dengan parkir serta aspek-aspek yang menunjang parkir lainnya yaitu perabot jalan. Paskal 23 awalnya adalah kawasan pertokoan berupa deretan ruko 23 Paskal Shopping Center berlokasi di kawasan one stop business strategis di pusat kota Bandung. Tujuan penulisan ini adalah mengidentifikasi transformasi pada elemen-elemen fisik yang difokuskan pada parkir, perabot jalan yang berpotensi membentuk kawasan Paskal Hypersquare. Metode yang digunakan menggunakan metode penelitian kualitatif dengan teknik observasi lapangan, pendekatan studi dengan morfologi kota, dan dilihat secara diakronik, yaitu menganalisis transformasi parkir, dan perabot jalan, pada kawasan Paskal Hypersquare berdasarkan data sebelum hingga sesudah Mall 23 Paskal dibangun. Data-data diperoleh dari observasi langsung ke wilayah penelitian dan observasi pustaka lain, serta pembahasan yang bersifat deskriptif. Dari hasil penelitian dapat disimpulkan bahwa secara keseluruhan transformasi elemen-elemen fisik kota terkait Parkir adalah adanya penambahan parkir pada Mall 23 Paskal. Terkait perabot jalan dapat disimpulkan bahwa setelah Mall 23 Paskal dibangun ada penambahan elemen fisik yang mendukung pada pencapaian ke arah Mall 23 Paskal. Elemen parkir dan perabot jalan sangatlah berpengaruh terhadap pembentuk kawasan di Paskal Hypersquare. Elemen fisik pembentuk kawasan Paskal Hypersquare telah memenuhi aspek perencanaan sebuah kawasan.
\end{abstract}

Kata Kunci: Transformasi, Parkir, Perabot jalan, Paskal Hypersquare,

\begin{abstract}
The development of malls in the city of Bandung undergo a transformation. A total of nine mall (rental and strata) new period 2014 to 2017 One of the malls is 23 Paskal Shopping Center located in one stop strategic business area in downtown Bandung. The purpose of this paper is to identify the transformation of physical elements which is focused on parking, street furniture that potentially form the Paskal Hypersquare area. The method use qualitative research method with field observation technic, morphology of the city study approach, and seen diacronically, i.e analyzing the transformation of parking, street furniture, and signage at Paskal Hypersquare area based on data before and after Mall 23 Paskal is built. The data are obtained from direct observation to research area and other literature observation, as descriptive discussion. From the results of the study can be concluded that the overall transformation of physical elements of the city, according to parking there the addition of parking at Mall 23 Paskal. Related Street Furniture can be concluded that after Mall 23 Paskal built there is addition of physical elements that support the achievement toward the Mall 23 Paskal. Elements Parking, Street Furniture, and Signage is very influential on the forming of the area in Paskal Hypersquare. Physical element forming Paskal Hypersquare area has met the aspect of planning as a shopping mall.
\end{abstract}

Keywords: Transformation, Parking, Street Furniture, Hypersquare Paskal, 


\section{Perubahan Pola Parkir Akibat dari Penambahan Fungsi Bangunan di Kawasan Paskal Hypersquare di Kota Bandung}

\section{PENDAHULUAN}

Pembangunan di kota-kota di Indonesia sangat pesat seiring dengan kebutuhan perumahan dan sarana dan prasarananya. Pembangunan ber skala besar tumbuh di kota-kota besar, demikian pula dengan pusat perbelanjaan mal yang tumbuh bagaikan jamur yang dilaksanakan oleh pembangun swasta [1]. Perkembangan kota tersebut sangat erat kaitannya dengan persoalan parkir yang disediakan pada setiap pembangunan di kota.[2]

Dalam teori urban design terdapat elemen-elemen yang meliputi tata guna lahan (land use), bentuk dan massa bangunan (building form and massing), sirkulasi dan parkir (circulation and parking), ruang terbuka (open space), jalur pedestrian (pedestrian way), aktivitas pendukung (activity support), ramburambu (signage) dan preservasi (preservation). [3] Panduan rancang kota adalah satu set perangkat panduan dan peraturan yang digunakan untuk mengatur dan membatasi penggunaan dan pengembangan ruang kota dan arsitektur kota.[4]

Kota Bandung yang sejak dahulu memiliki citra sebagai kota dengan beragam kekhasan, menjadi daya tarik tersendiri bagi masyarakat Indonesia. Bandung dikenal sebagai surga belanja bagi masyarakat Indonesia. Perkembangan mal di Kota Bandung mengalami transformasi yang diakibatkan oleh penambahan bangunan beserta fungsinya, terdapat sembilan mal (sewa dan strata) baru pada kurun tahun 2014 hingga tahun 2017. [5]

Salah satu diantara mal tersebut adalah 23 Paskal Shopping Center yang berlokasi di kawasan one stop business strategis di pusat kota Bandung. 23 Paskal Shopping Center salah satu destinasi wisata yang menyediakan segala kebutuhan tersebut terdapat di kawasan Paskal Hypersquare. Terdapat berbagai area didalamnya, diantaranya main enterance building, mall, food market, hotel, condominium, dan service apartment sehingga kawasan ini bertransformasi menjadi sebuah kawasan one stop business yang strategis dipusat kota Bandung. Fungsi bangunan yang ditambahkan adalah bangunan mall dan universitas dalam satu massa bangunan, yang diletakkan di bagian belakang kawasan. Penambahan fungsi dan bangunan tersebut menyebabkan terjadinya perubahan pada kawasan terutama pada permasalahan eksternal ruang yaitu ruang antara bangunan yang berfungsi sebagai parkir. Perubahan yang terjadi tersebut antara lain pada pola sirkulasi kendaraan menuju parkir, exit/keluar dari kawasan, jumlah penambahan kendaraan mobil dan motor.

Elemen parkir memiliki dua pengaruh langsung pada kualitas lingkungan, yaitu kelangsungan aktivitas komersial dan pengaruh visual pada struktur dan bentuk fisik kota.[3]

Standar yang dipakai di Indonesia Law sudah diatur oleh Departemen Perhubungan, dan harus dipenuhi oleh pemilik setiap bangunan komersial.[6] Parkir memainkan peran penting dalam menyediakan mobilitas dan aksesibilitas ke berbagai tempat, unsur-unsur nya antara lain: 1) Dimensi Tempat Parkir, 2) Jalur, 3) Lebar Jalan Masuk, 4) Jumlah Jalur Jalan Masuk, 5) Grades, (Kelas), 6) Kepulauan Akhir (End Island), 7) Overhang, roda berhenti dan bemper.[7]

Keberhasilan sebuah mal sangat tergantung kepada banyak aspek [8] dan diantaranya kenyamanan dan kemudahan fasilitas parkir bagi pengunjung, yaitu kemudahan dan kelancaran alur parkir dari mulai masuk ke kawasan, melakukan parkir, and keluar dari kawasan.[9]

Pola parkir digambarkan dengan bentuk alur seperti pada gambar 1, yaitu pola sirkulasi linear, fasilitas utama sebagai pusat dan fasilitas lainnya berada pada suatu jarak, pola sirkulasi hirarkis, sirkulasi dalam dengan fasilitas terpusat di pheriperi, fasilitas terpusat dengan sirkulasi pheriperi, pola radial, bentuk pohon bercabang. 


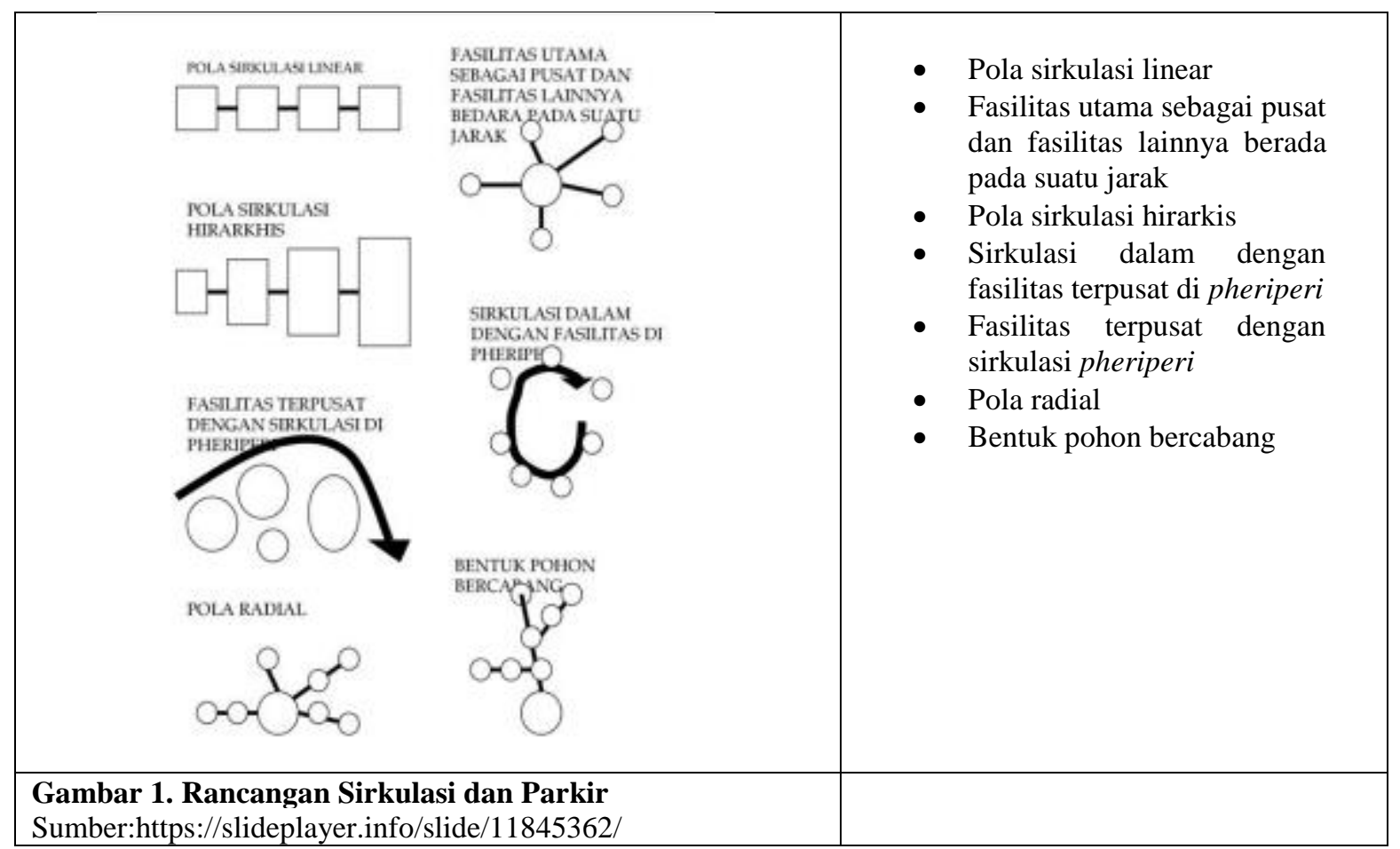

NACTO (National Association of City Transportation Officials) dalam bukunya yang berjudul Urban Street Design Guide memaparkan jalur trotoar terdiri dari 4 (empat) zona, yaitu; 1) Frontage zone (zona depan), 2) Pedestrian through zone (zona pejalan kaki), 3) Street furniture/curb zone (zona pinggir jalan), 4) Enhancement/buffer zone (zona penyangga).[10]

Rubenstein (1992) dalam bukunya yang berjudul Pedestrian Malls, Streetscapes, and Urban Spaces memaparkan dalam merancang dan memilih perabotan untuk mall, streetscape, atau plaza harus dilakukan pendekatan dalam konteks lingkungan kota yang komprehensif dan lokasi spesifik dimana perabotan jalan (street furniture) akan digunakan. Dalam merancang, desain mall atau plaza harus mempertimbangkan tipe, ukuran, lokasi skala, dan bahan dari semua perabot jalan (street furniture). Unsur-unsur ini meliputi paving, pencahayaan, desain grafis, patung, air mancur, bollards, tempat duduk, taman, telepon, kios, tempat penampungan, kanopi, wadah sampah, dan air mancur. Pertimbangan dalam perancangan, perincian, dan pilihan bahan yang digunakan dalam perabot adalah penting, tidak hanya untuk kontinuitas desain, namun juga untuk ketahanan dan kemudahan dalam perawatan. Perincian dan penggunaan material yang sesuai dalam lanskap perkotaan sangat penting bagi keberhasilan suatu mall, streetscape, atau plaza. Perancang perkotaan yang berpengalaman dan arsitek lansekap harus dilibatkan dalam perancangan dan koordinasi tahap pengembangan proyek ini. [11]

Kawasan Paskal Hypersquare sangat berpengaruh terhadap lingkungan di sekitarnya, dan oleh karena citra kawasan Paskal Hypersquare yang dikenal sebagai kawasan perniagaan kelas menengah atas, hal ini cukup menimbulkan persepsi mengenai karakteristik kawasan dilihat dari elemen fisik penting yang terdapat di kawasan tersebut anatara lain perpakiran dan perabot jalan.

Berdasarkan latar belakang tersebut, maka rumusan masalah dalam penelitian ini adalah sebagai berikut: 1) Bagaimana perubahan massa pada kawasan Paskal Hypersquare, 2) Bagaimana perubahan pola alur parkir yang terbentuk karena penambahan fungsi di kawasan tersebut, 3) Bagaimana ketersediaan perabot jalan sebagai penunjang parkir

Penelitian ini bertujuan untuk mengkaji transformasi yang terjadi pada elemen-elemen fisik yang berpotensi dalam membentuk kawasan Paskal Hypersquare di Jalan Pasir Kaliki, Bandung, yaitu mengenai perubahan pola sirkulasi, dan kelengkapan perabot jalan yang merupakan salah satu nilai tambah dan potensi bagi kemudahan pengunjung yang datang. 


\section{METODOLOGI}

Metode yang digunakan menggunakan metode penelitian analisis deskriptif secara kualitatif dengan teknik observasi di lapangan. Pendekatan studi dengan morfologi kota, dan dilihat secara diakronik, yaitu menganalisis transformasi parkir, dan perabot jalan pada kawasan Paskal Hypersquare berdasarkan data sebelum hingga sesudah Mall 23 Paskal dibangun. Langkah pertama adalah menghimpun data sekunder pola perparkiran dari data sebelum Mall 23 Paskal dibangun, kemudian selanjutnya meng observasi di lapangan pola perparkiran setelah adanya Mall 23 Paskal. Kajian dilakukan dengan menganalisa berdasarkan teori, standar, pedoman yang berlaku di Indonesia juga studi-studi yang sudah pernah dilakukan.

\section{HASIL DAN PEMBAHASAN}

Kawasan Paskal Hypersquare merupakan komplek bisnis yang terdiri dari main enterance building, mall, food market, hotel, condominium, dan service apartement. Terdapat 2 (dua) jalan besar yang membatasi kawasan ini, Jalan Pasir Kaliki di sepanjang sisi Barat dan Jalan Kebon Jati di sepanjang sisi Selatan. Kedua jalan ini merupakan jalan yang cukup besar dan ramai aktivitas masyarakat. Di sisi Utara, Paskal Hypersquare berbatasan dengan rel kereta api yang terhubung Stasiun Kereta Api Bandung, tidak jauh dari lokasi tapak. Adapun di sisi Timur berbatasan dengan lahan pemukiman warga. Kawasan Paskal Hypersquare memiliki luas \pm 1.7 hektar/17.000 m2

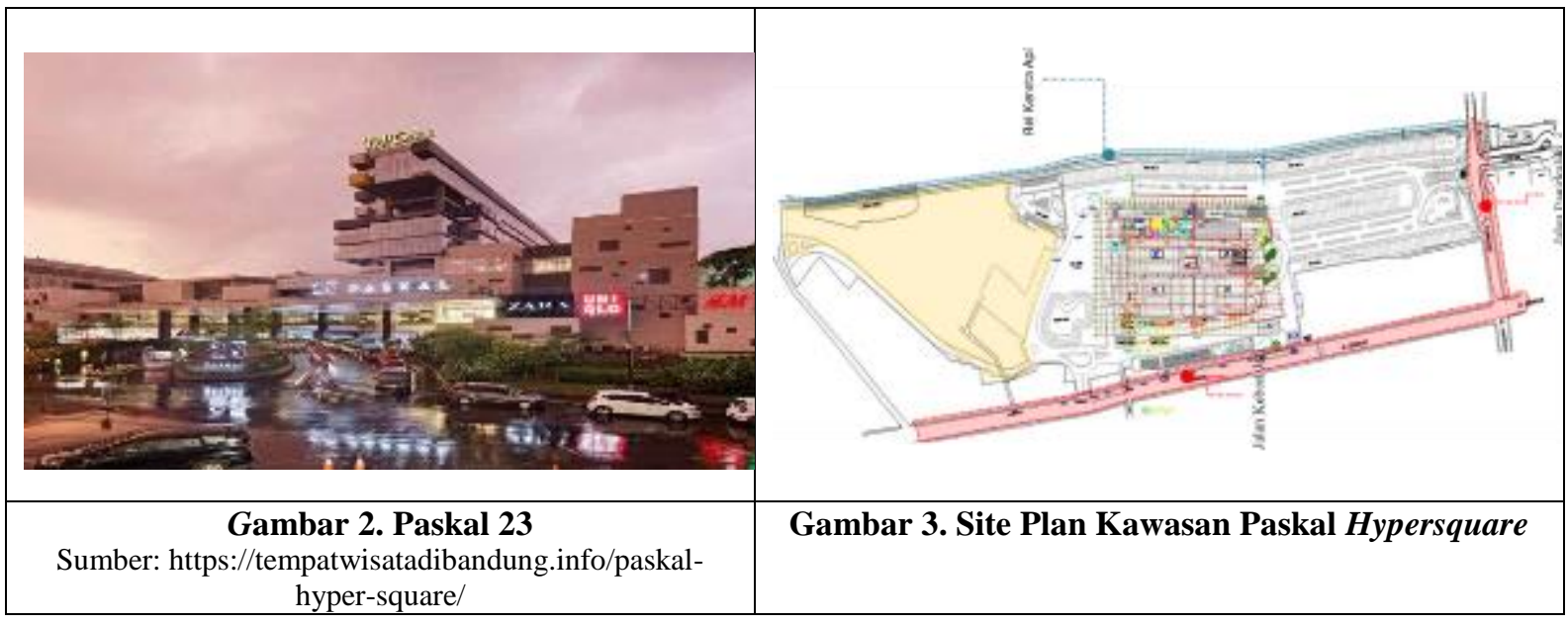

\subsection{Analisis Parkir}

Tiap-tiap bangunan dalam kawasan tersebut menyediakan area parkir. Fasilitas utama pada parkir di kawasan ini sebagai berikut : a. Parkir basement. Terdapat parkir kendaraan di basement mall 23 Paskal. b. Parkir off-street. Parkir ini terdapat di setiap pertokoan di sekitar kawasan Paskal Hypersquare dan di sisi mall 23 Paskal. c. Parkir on-street. Parkir ini terletak di badan jalan di kawasan Paskal Hypersquare.

Adapun elemen fisik yang berupa parkir yang terdapat di Kawasan Paskal Hypersquare sebagai berikut:

\section{Tempat Parkir}

\section{a. Dimensi Parkir Mobil}

Pada kawasan Paskal Hypersquare sebelum Mall 23 Paskal dibangun terdapat parkir mobil pada area on street (parkir ruko) dengan ukuran $480 \mathrm{~cm} \times 320 \mathrm{~cm}$. Adanya penambahan parkir mobil pada area off street (Mall 23 Paskal) dengan ukuran 233,33 cm x $500 \mathrm{~cm}$. Dari Hasil analisis, di atas dapat disimpulkan bahwa berdasarkan data Dirjen Perhubungan Darat tahun 1996, dimensi parkir mobil On street dan Off street di kawasan Paskal Hypersquare masih belum memenuhi standar parkir. Adanya 
penembahan jumlah parkir di kawasan Paskal Hypersquare yaitu penambahan parkir motor di dalam bangunan Mall 23 Paskal.

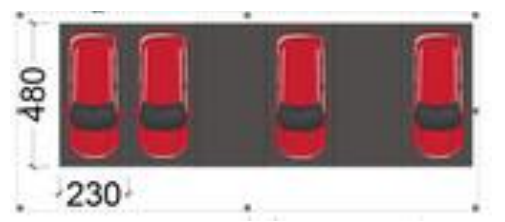

Gambar 4. Dimensi Mobil on street (area ruko) (sumber: Hasil analisis, 2017)

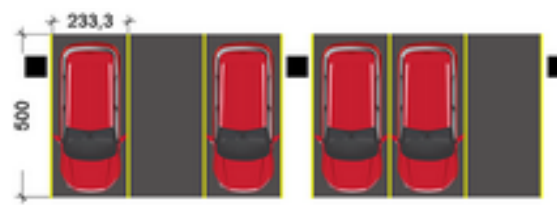

Gambar 5. Dimensi Mobil off street (Mall 23 Paskal) (sumber: Hasil analisis, 2017)

\section{b. Dimensi Parkir Motor}

Pada kawasan Paskal Hypersquare sebelum Mall 23 Paskal terbangun terdapat parkir motor on street (parkir ruko) dengan ukuran $150 \mathrm{~cm}$ x $80 \mathrm{~cm}$. Adanya penambahan parkir motor off street (Mall 23 Paskal) dengan ukuran $150 \mathrm{~cm} \times 80 \mathrm{~cm}$. Dari Hasil analisis, di atas dapat disimpulkan bahwa berdasarkan data Dirjen Perhubungan Darat tahun 1996, dimensi parkir motor dikawasan Paskal Hypersquare yang digunakan masih belum memenuhi standar parkir. Transformasi yang terjadi di kawasan Paskal Hypersquare adanya penambahan tempat parkir motor di dalam bangunan Mall 23 Paskal.

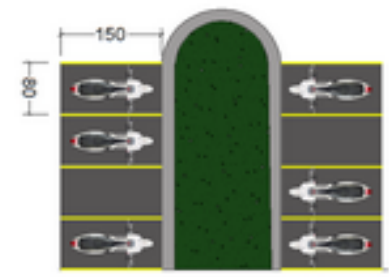

Gambar 6. Dimensi parkir motor

\section{Berdasarkan Pola}

(sumber: Hasil analisis, 2017)

\section{a. Pola Parkir Satu Sisi}

Pada kawasan Paskal Hypersquare sebelum Mall 23 Paskal terbangun pola parkir yang digunakan pada area parkir ruko adalah pola parkir satu sisi membentuk sudut $90^{\circ}$. Pola yang digunakan saat Mall 23 Paskal terbangun tidak mengalami perubahan. Dari Hasil analisis, diatas dapat disimpulkan bahwa ada dua jenis pola parkir yang digunakan pada kawasan Paskal Hypersquare adalah pola satu sisi yang membentuk $90^{\circ}$ yang diterapkan pada parkir di area ruko.

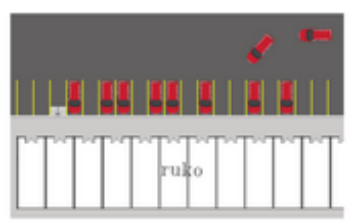

Gambar 7. Pola parkir satu sisi area ruko (sumber: Hasil analisis, 2017)

\section{b. Pola Parkir Pulau}

Pola parkir motor menggunakan pola parkir pulau yang membentuk sudut 90o ditinjau dari transformasi secara keseluruhan, penambahan parkir pada bangunan Mall 23 Paskal tidak mempengaruhi pola parkir dan tidak ada perubahan pola parkir di kawasan Paskal Hypersquare.

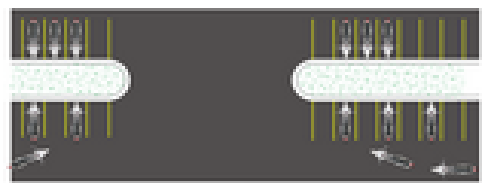

Gambar 8. Pola parkir pulau, parkir motor (sumber: Hasil analisis, 2017)

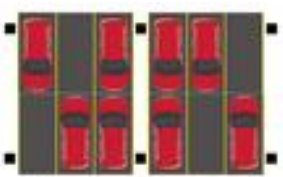

Gambar 9. Pola parkir pulau, mobil dalam Mall 23 Paskal (sumber: Hasil analisis, 2017) 
Perubahan Pola Parkir Akibat dari Penambahan Fungsi Bangunan di Kawasan Paskal Hypersquare di Kota Bandung

\section{Jalur}

Pada kawasan Paskal Hypersquare ukuran jalur masing masik memiliki dimensi :

- Untuk jalan 1 arah 3.5- 4 meter

- Untuk jalan 2 arah 7- 8 meter

Dari hasil analisis, diatas dapat disimpulkan bahwa berdasarkan peraturan Dirjen Perhubungan Darat, untuk standar dimensi jalur pada kawasan Paskal Hypersquare sudah memenuhi standar. Jalur pada kawasan Paskal Hypersquare tidak mengalami perubahan.

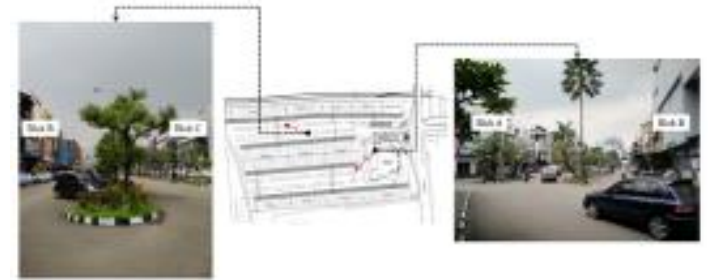

Gambar 10. Jalur pada kawasan Paskal (sumber: Hasil analisis, 2017)

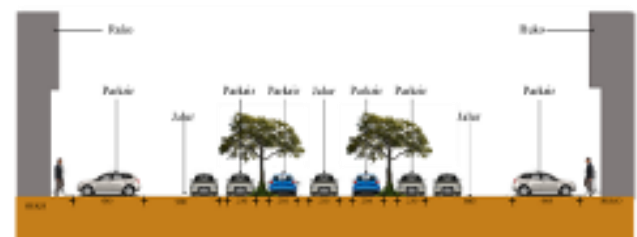

Gambar 11. Potongan Jalur pada kawasan Paskal (sumber: Hasil analisis, 2017)

\section{Lebar Jalan Masuk dan Keluar}

Pada kawasan Paskal Hypersquare sebelum dan sesudah Mall 23 Paskal lebar pintu keluar masuk tidak mengalami perubahan. Dimensi lebar jalan masuk dan keluar 9 meter dengan sistem satu arah, dapat dilewati 2 mobil sekaligus, panjang total pintu 18 meter untuk jalan. Panjang dapat menampung \pm 3 mobil secara berurutan. Dari Hasil analisis, diatas dapat disimpulkan bahwa Kawasan Paskal Hypersquare lebar jalan keluar masuk masing-masing 9 meter dengan sistem satu arah. Dengan demikian, jalur masuk ini dapat dilewati 2 mobil sekaligus. Panjang dapat menampung 3 mobil sekaligus sesuai dengan peraturan maka dapat dikatakan jalur masuk sudah memenuhi standar.

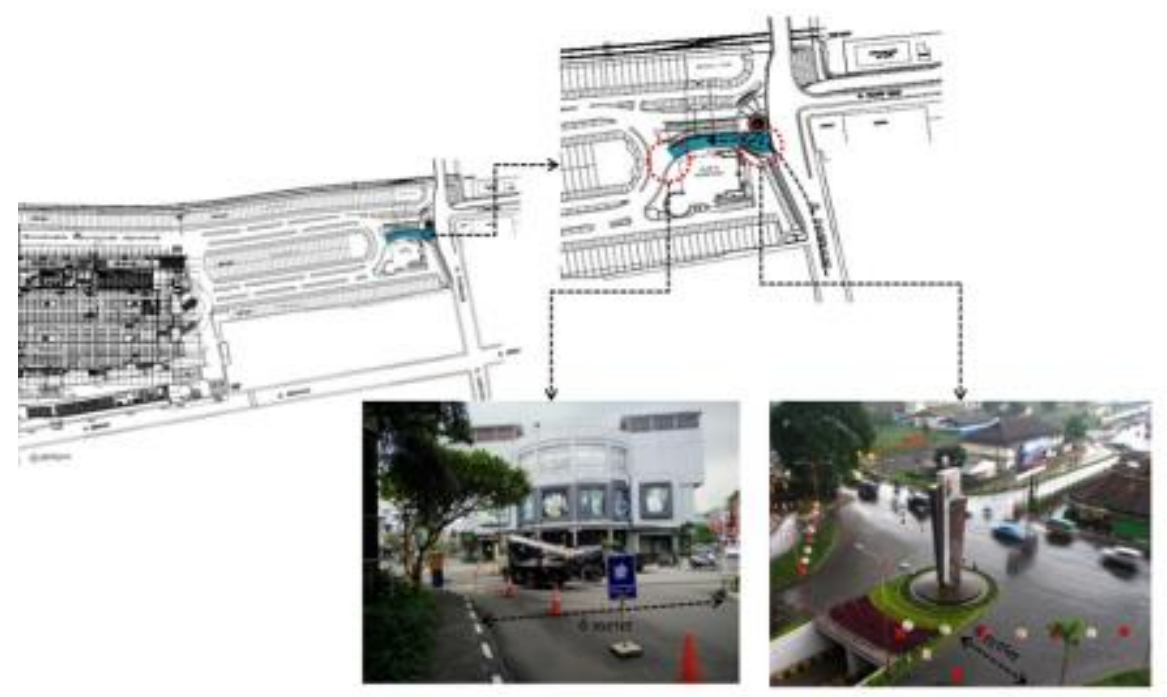

Gambar 12. Jalan masuk dan keluar kawasan Paskal Hypersquare (sumber: Hasil analisis, 2017)

\section{Jumlah Jalur Masuk dan Keluar}

Pada Kawasan Paskal Hypersquare sebelum Mall 23 Paskal dibangun jalur masuk sebagai aksesibilitas untuk kendaraan, terletak di jalan Pasir Kaliki dan jalan Kebon Jati. Setelah adanya Mall 23 Paskal jalur masuk tidak ada perubahan, sedangkan ada penambahan yang terdapat pada jalur keluar yang semula jalur keluar hanya ada 2 bertambah menjadi 3 jalur keluar. Dari hasil analisis, diatas dapat disimpulkan bahwa jumlah jalur masuk pada kawasan Paskal Hypersquare dapat dikatakan sudah memenuhi standar 
jumlah dapat dilihat dari akesibilitas untuk keluar masuk kendaraan dapat diakses dari 2 jalan yaitu jalan Pasir Kaliki dan jalan Kebon Jati.

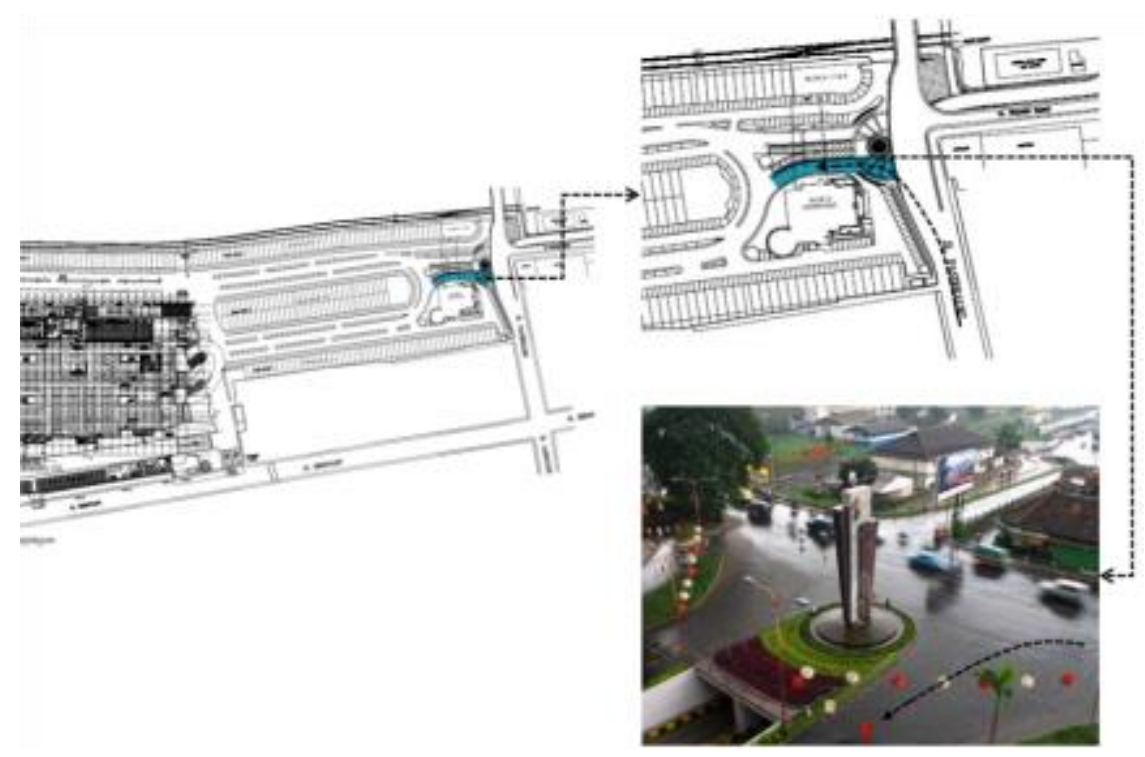

Gambar 13. Jumlah jalur masuk dan keluar

\section{Antrian}

(sumber: Hasil analisis, 2017)

Antrian pada kawasan Paskal Hypersquare ini berada di center/pintu masuk utama yang berada di jalan Pasir Kaliki. Panjang antrian dapat menampung \pm 3 mobil secara berurutan. Dari hasil analisa diatas dapat disimpulkan bahwa berdasarkan peraturan, antrian pada kawasan Paskal Hypersquare sudah cukup memadai.

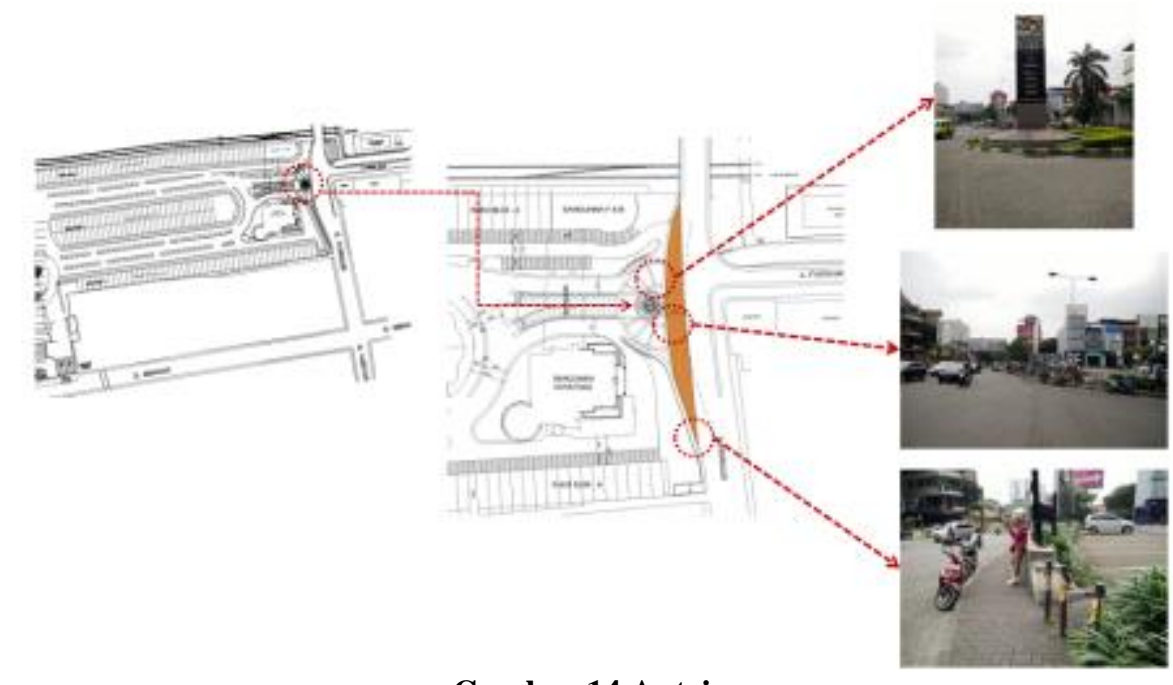

Gambar 14 Antrian

(sumber: Hasil analisis, 2017)

\section{Kepulauan Akhir (End Island)}

End Island di kawasan Paskal Hypersquare terdapat di setiap batas parkir on street, yang digunakan sebagai pembatas, dan tempat untuk manuver kendaraan yang akan berbelok. End Island di kawasan ini juga digunakan sebagai media tanam pohon untuk melindungi kendaraan yang parkir. Dari Hasil analisis, diatas dapat disimpulkan bahwa untuk kelengkapan parkir khususnya End Island di kawasan Paskal Hypersquare telah memenuhi syarat parkir untuk memberikan kemudahan parkir kendaraan, ketika melakukan parkir ataupun manuver kendaraan. 


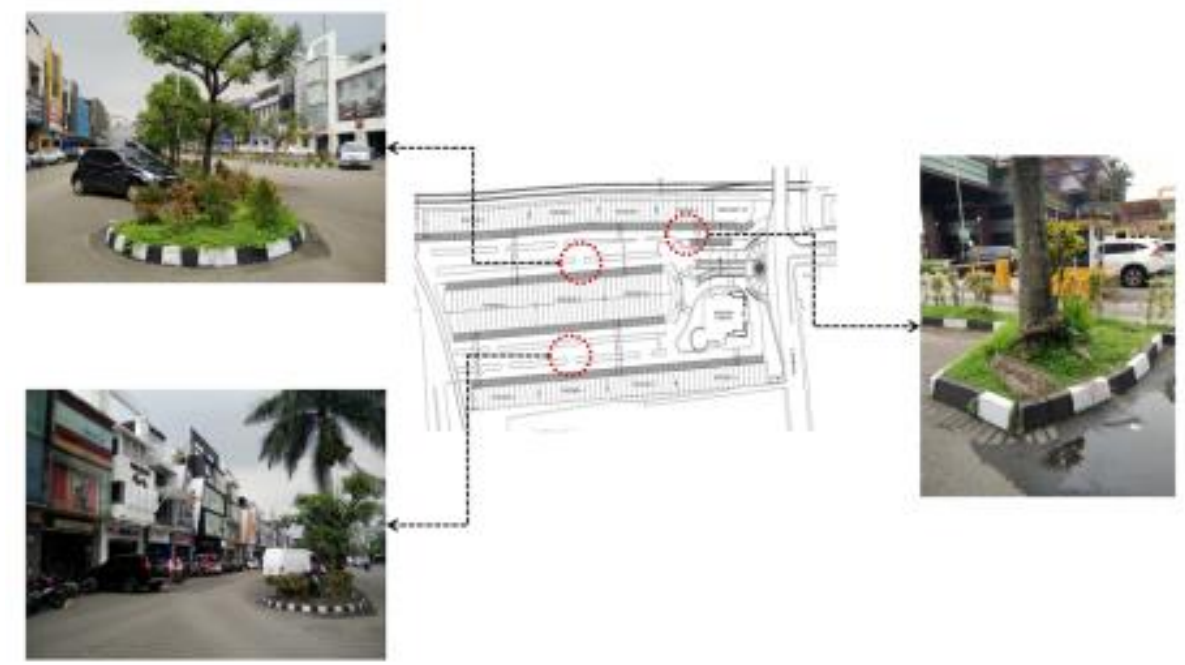

Gambar 15. Kepulauan Akhir (end island)

(sumber: Hasil analisis, 2017)

\section{Overhang}

Area parkir di kawasan Paskal Hypersquare dilengkapi dengan garis-garis batas berwarna kuning untuk merapikan formasi parkir. Dari Hasil analisis, diatas dapat disimpulkan bahwa untuk kelengkapan parkir khususnya Overhang di kawasan Paskal Hypersquare telah memenuhi syarat parkir.

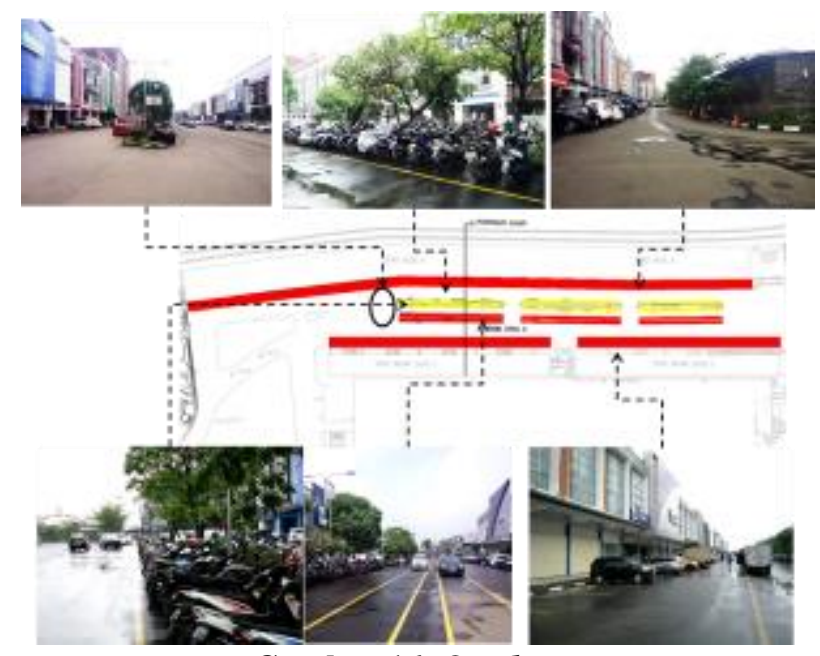

Gambar 16. Overhang

(sumber: Hasil analisis, 2017)

\section{Alur}

Dari hasil analisis, diatas dapat disimpulkan bahwa pola ruangan pada Kawasan Paskal Hypersquare dilihat dari pola lama dan baru tidak mengalami perubahan. Secara garis besar bentuk pola yang ada baik yang baru maupun yang lama tetap menggunakan pola terklaster. Adanya penambahan massa bangunan (Mall 23 Paskal) di kawasan tersebut tidak begitu mempengaruhi alur kawasan tetapi lebih kepada menambah alur masuk dan keluar ke arah bangunan 23 Paskal. Transformasi pada kawasan Paskal Hypersquare dikaji dari parkir yaitu adanya penambahan jumlah parkir karena adanya penambahan bangunan Mall 23 Paskal, jadi alur bertambah dengan alur ke arah bangunan Mall 23 Paskal. 


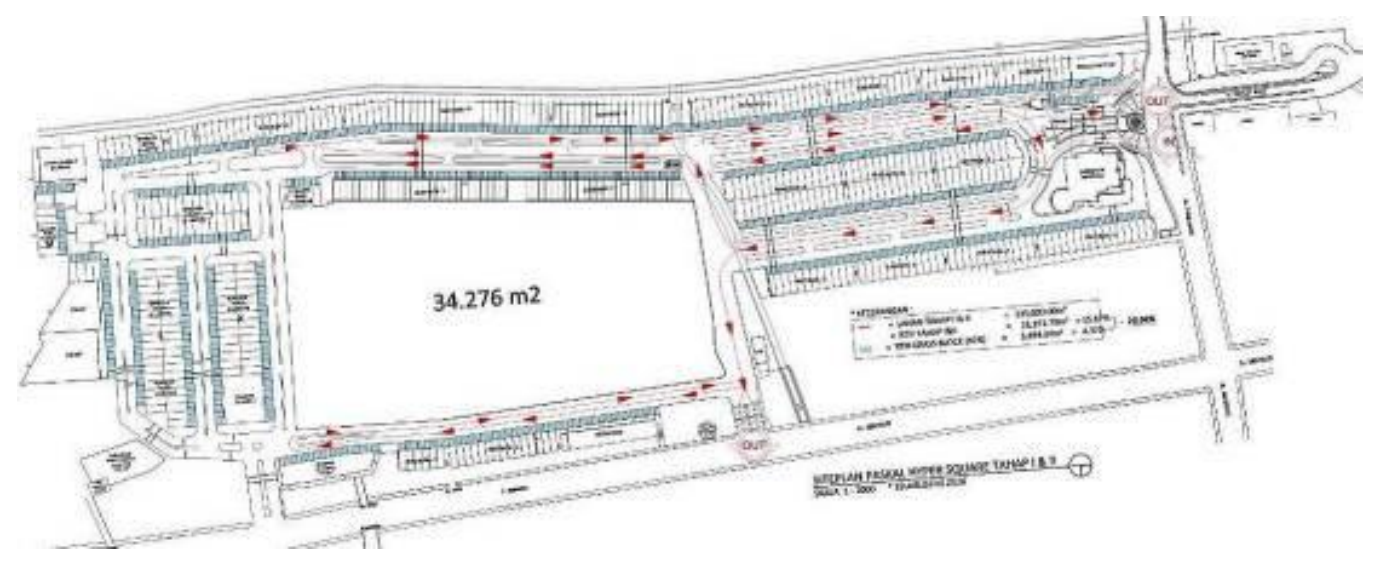

Gambar 17. Alur kendaraan kawasan Paskal Hypersquare (sebelum Mall 23 Paskal dibangun) (sumber: Hasil analisis, 2017)

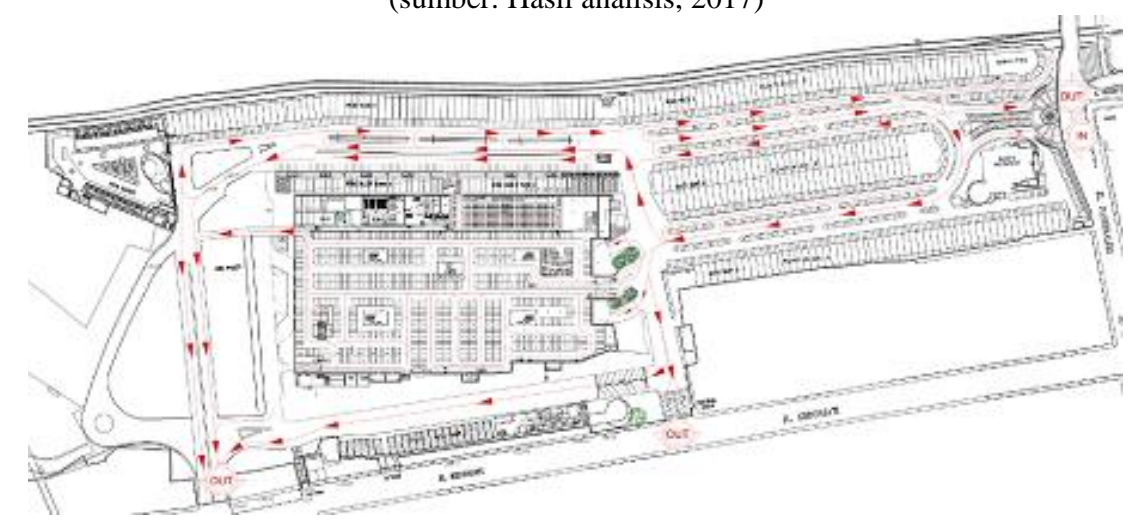

Gambar 18. Alur kendaraan kawasan Paskal Hypersquare (sesudah Mall 23 Paskal dibangun) (sumber: Hasil analisis, 2017)

\subsection{Analisis Perabot Jalan}

Rubenstein (1992) dalam bukunya yang berjudul Pedestrian Malls, Streetscapes, and Urban Spaces memaparkan dalam merancang dan perabotan untuk mall, streetscape, atau plaza harus dilakukan pendekatan dalam konteks lingkungan kota yang komprehensif dan lokasi spesifik dimana perabotan (perabot jalan) akan digunakan. Dalam merancang, desain mall atau plaza harus mempertimbangkan tipe, ukuran, lokasi skala, dan bahan dari semua Perabot Jalan. Unsur-unsur ini meliputi paving, beton (concrete), batu (stone), aspal (aspalt), daya tahan dan kemudahan pemeliharaan, pohon (tree grates), sumber cahaya (light sources), desain grafis, sclupture, bollard, tempat duduk, kanopi, tempat sampah, dan air mancur.[11]

\section{Paving}

Pada kawasan Paskal Hypersquare pengggunaan material paving digunakan di beberapa bagian entrance masuk kawasan Paskal Hypersquare dan entrance masuk 23 Paskal Hypersquare sebagai pembeda.

\section{Beton (Concrete)}

Penggunaan material kanstin beton sebagai penguat tepi jalan dan dapat menambah nilai estetika dan kerapian dari trotoar jalan. 


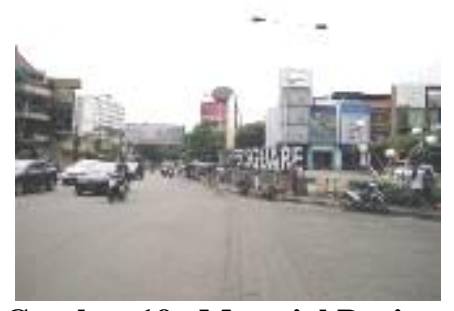

Gambar 19. Material Paving (sumber: hasil survey, 2017)

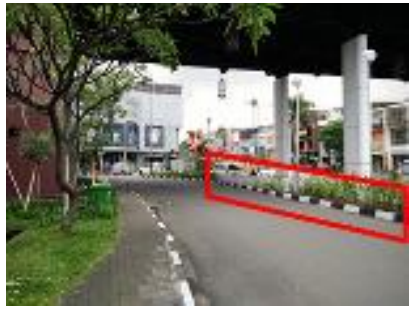

Gambar 20. Material Beton (Concrete)

(sumber : hasil survey, 2017)

\section{Batu (Stone)}

Penggunaan beton sebagai material kanstin. Kanstin beton digunakan pada trotoar di Kawasan Paskal Hypersquare sebagai pembatas antara pedestrian dan jalur kendaraan. Penggunaan material koral sikat dan batu alam digunakan sebagai penutup finishing lantai atau dinding untuk mempercantik suatu bangunan.

\section{Aspal (Asphalt)}

Penggunaan material aspal pada jalan kawasan Paskal Hypersquare sebagai pembeda antara jalur kendaraan dan jalur untuk pejalan kaki. Aspal berfungsi untuk mengikat batuan agar tidak lepas dari permukaan jalan akibat lalu lintas (waterproofing, protect) terhadap erosi air.

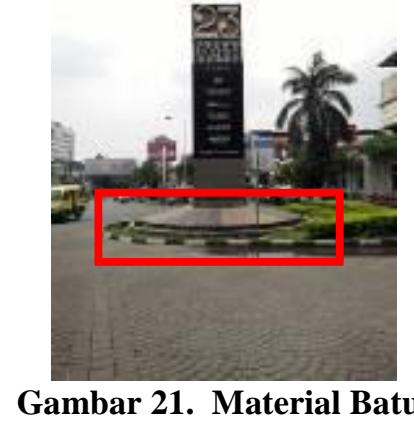

Gambar 21. Material Batu
(sumber: hasil survey, 2017)

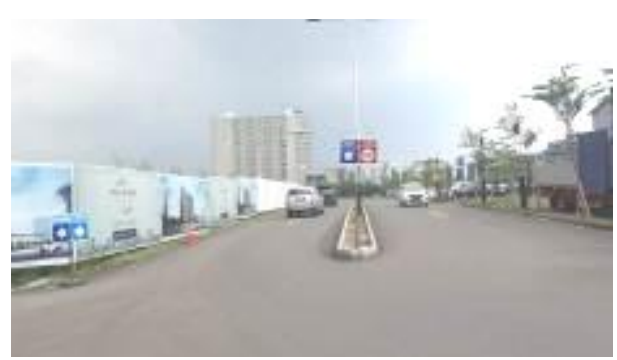

Gambar 22. Material Aspal (sumber : hasil survey, 2017)

\section{Daya Tahan dan Kemudahan Pemeliharaan (Durability and Ease of Maintenance)}

Peletakan pemeliharan pada kawasan Paskal Hypersquare, cukup terjangkau. Hanya peletakan bangunan terlihat bagi pengunjung, seperti tempat pembuangan sampah sementara.

\section{Pohon (Tree Grates)}

Pohon digunakan untuk memberi jarak antara jalur pejalan kaki dan jalur kendaraan. Kegunaan tanaman pada jalur tepi jalan dan median jalan diantaranya sebagai peneduh, penyerap polusi udara, peredam kebisingan, dan pemecah angin.

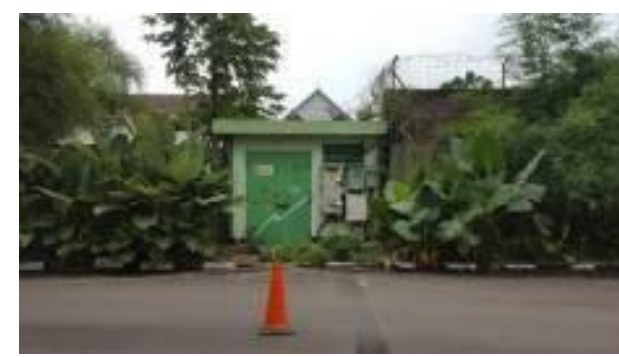

Gambar 23. Ruangan Pemeliharaan PLN (sumber: hasil survey, 2017)



Gambar 24. Elemen Vegetasi (Pohon) (sumber : hasil survey, 2017) 


\section{Sumber Cahaya (Light Sources)}

Sumber cahaya sebagai penerangan pada malam hari berfungsi untuk meningkatkan keselamatan dan kenyamanan pengendara, keamanan lingkungan, memberikan kenyamanan dan keindahan kawasan tersebut.

\section{Desain Grafis (Graphic Design)}

Desain grafis berupa signage tersebut berupa letter abjad yang membentang dan terbaca dengan jelas. Signage tersebut berfungsi sebagai mall identity yang menandakan pengunjung sedang memasuki kawasan Paskal Hypersquare.[11]

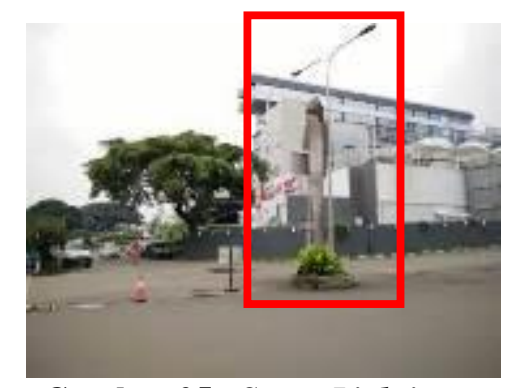

Gambar 25. Street Lighting

(sumber: hasil survey, 2017)

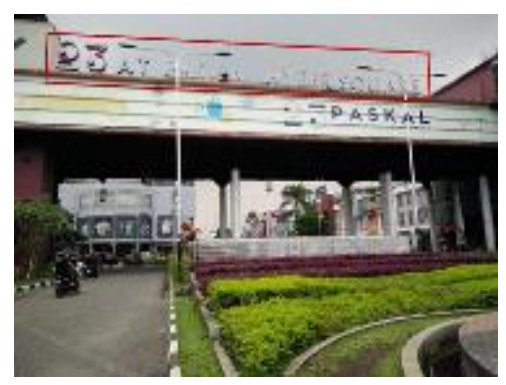

Gambar 26. Desain Grafis

(sumber : hasil survey, 2017)

\section{Sclupture}

Sclupture pada kawasan Paskal Hypersquare terletak di pintu masuk yang berada di Jalan Pasir kaliki sebagai identitas kawasan, juga sebagai penanda pengunjung telah mamasuki kawasan tersebut.

\section{Bollard}

Penggunaan bollard pada kawasan Paskal Hypersquare hanya berada di depan kawasan (entrance in).

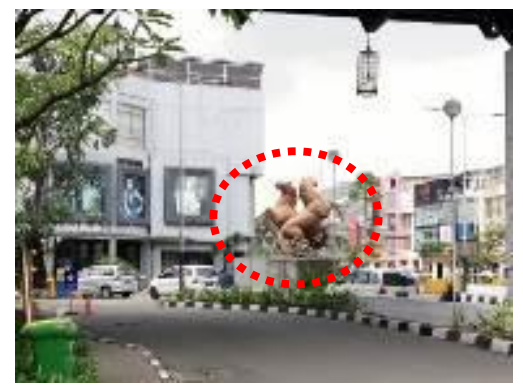

Gambar 27. Sclupture

(sumber: hasil survey, 2017)



Gambar 28. Bolllard

(sumber : hasil survey, 2017)

\section{Tempat Duduk}

Penggunaan tempat duduk pada kawasan Paskal Hypersquare tidak disediakan diberbagai tempat, tempat duduk hanya tersedia di dalam Mall 23 Paskal Shopping Center dan di kawasan.

\section{Kanopi}

Penambahan kanopi pada ruko di kawasan Paskal Hypersquare menandakan fungsi dari ruko tersebut, tetapi beberapa tidak menggunakan kanopi tambahan melainkan hanya menggunakan signage pada ruko tersebut. 




Gambar 29. Tempat Duduk

(sumber: hasil survey, 2017)

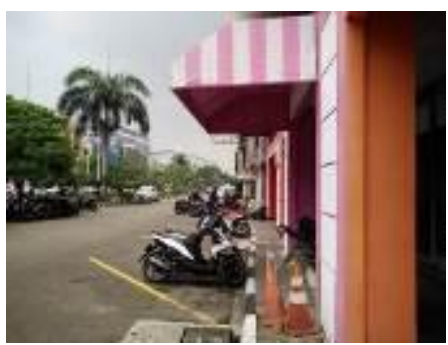

Gambar 30. Kanopi

(sumber : hasil survey, 2017)

\section{Tempat Sampah}

Pada kawasan Paskal Hypersquare untuk fasilitas tempat sampah sudah tersedia dengan baik dan pengunjung dapat menemukan tempat sampah dengan mudah.

\section{Air Mancur}

Pada kawasan Food Market terdapat air mancur yang dapat memperindah kawasan tersebut. Suara air mancur dapat memberikan efek ketenangan.

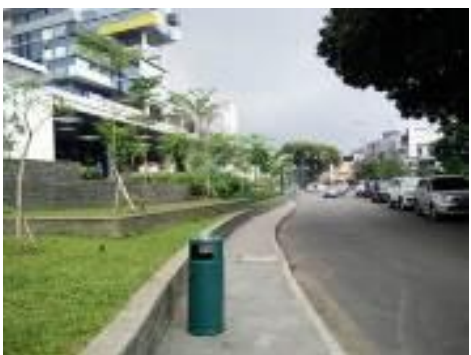

Gambar 31. Tempat Sampah

(sumber: hasil survey, 2017)

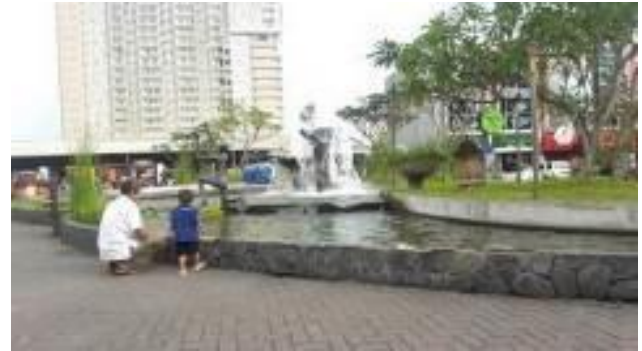

Gambar 32. Air Mancur

(sumber : hasil survey, 2017)

\section{SIMPULAN}

Pola alur sirkulasi parkir di Paskal Hypersquare Bandung sebelum adanya Mall 23 Paskal memakai pola konsep fasilitas terpusat dengan sirkulasi pheriperi, yaitu alur sirkulasi mengelilingi fasilitas utama. Setelah adanya Mall 23 Paskal sirkulasi pola alur masih tetap sama dan terpisah dengan alur sirkulasi bangunan Mall 23 yang berada didalam bangunan. Pola parkir yang digunakan adalah pola linier dengan klaster-klaster di beberapa kantung, yaitu kantung parkir on street ruko kawasan lama, dan belakang bangunan Mall 23 Paskal, serta kantung parkir off street di dalam bangunan Mall 23 Paskal. Pintu masuk ke kawasan masih tetap dari jalan Pasir kaliki baik melewati underpass maupun langsung, sedangkan jalan keluar dari kawasan ditambah 1 buah menjadi 3 buah, 2 buah keluar menuju jalan Kebon Jati, 1 buah menuju jalan Pasir Kaliki.

Adanya transformasi berupa penambahan massa bangunan (Mall 23 Paskal) pada kawasan Paskal Hypersquare tidak begitu besar memberi pengaruh pada pola alur parkir di kawasan tersebut. Secara garis besar bentuk pola yang ada baik yang baru maupun yang lama tetap menggunakan pola terkluster. Adanya penambahan massa bangunan (Mall 23 Paskal) dikawasan tersebut menambah alur masuk dan keluar ke arah bangunan 23 Paskal.

Berdasarkan hasil dan pembahasan tentang identifikasi transformasi elemen-elemen fisik kota terkait Parkir dan Perabot Jalan pada kawasan Paskal Hypersquare di Jalan Pasirkaliki, Bandung, dapat disimpulkan bahwa elemen-elemen fisik Parkir, Perabot jalan tersebut tersedia dan lengkap di kawasan Paskal Hypersquare. 
Berdasarkan hasil analisis, yang mengacu pada elemen parkir sebagai pembentuk kawasan Paskal Hypersquare, bahwa elemen parkir telah memenuhi kapasitas perparkiran dikawasan tersebut, dimana parkir merupakan salah satu sarana penunjang yang penting pada sebuah kawasan, jenis parkir di kawasan tersebut beragam terdapat parkir off street (kawasan Paskal Hypersquare) dan on street (mall 23 Paskal). Dari hasil penelitian Standar dimensi diukur berdasarkan standar Dinas Perhubungan Darat tahun 1996 belum memenuhi standar dimensi parkir di kawasan Paskal Hypersquare.

Berdasarkan hasil analisis, yang mengacu pada elemen Perabot Jalan sebagai pembentuk kawasan Paskal Hypersquare, bahwa menurut Rubenstein (1992) dalam bukunya yang berjudul Pedestrian Malls, Streetscapes, and Urban Spaces, Pada kawasan Paskal Hypersquare unsur-unsur yang meliputi paving, beton (concrete), batu (stone), aspal (aspalt), daya tahan dan kemudahan pemeliharaan, pohon (tree grates), sumber cahaya (light sources), desain grafis, sclupture, bollard, tempat duduk, kanopi, tempat sampah, dan air mancur telah tersedia dengan baik di kawasan tersebut.

Elemen Parkir dan Perabot Jalan sangatlah berpengaruh terhadap pembentuk kawasan di Paskal Hypersquare. Elemen fisik pembentuk kawasan Paskal Hypersquare tersebut telah memenuhi aspek perencanaan sebuah kawasan yang berfungsi sebagai mal.

\section{DAFTAR PUSTAKA}

[1] E. Japarianto and S. Sugiharto, "Pengaruh shopping life style dan fashion involvement terhadap impulse buying behavior masyarakat high income surabaya," J. Manaj. Pemasar., 2012, doi: 10.9744/pemasaran.6.1.32-41.

[2] Tom Rye, "Manajemen Parkir: Sebuah Kontribusi menuju Kota yang Layak Huni," Manaj. Park., 2010.

[3] H. Shirvani, "The Urban Design Process," Newyork: Van Nostrand Reinhold Company, 1985.

[4] M. Zahnd, Strategi Arsitektur 2 Perancangan sistem kota secara terpadu, Teori Perancangan Kota dan Penerapannya. 1999.

[5] R. Darwis, R. A. Hendraningrum, and Y. Adriani, "Kelayakan Fasilitas Publik Dalam Kawasan Industri Wisata Belanja Di Kota Bandung: Studi Kasus Terhadap Toilet Dan Musola," J. Kaji. Bahasan dan Pariwisata, 2016.

[6] Direktur Jendral Perhubungan Darat (Departemen Perhubungan), "Keputusan Direktur Jendral Perhubungan Darat Nomor : 272/HK.105/DRJD/96 tentang Pedoman Teknis Penyelenggaraan Parkir," Pedoman Park., 1996.

[7] J. W. Hill et al., Time-Saver Standards for Urban Design. 2003.

[8] Y. T. Wong, S. Osman, A. Jamaluddin, and B. C. Yin-Fah, "Shopping motives, store attributes and shopping enjoyment among Malaysian youth," J. Retail. Consum. Serv., 2012, doi: 10.1016/j.jretconser.2012.01.005.

[9] B. Suri, P. K. Dutta Pramanik, and S. Taneja, "An Efficient Parking Solution for Shopping Malls Using Hybrid Fog Architecture,” 2020, doi: 10.1007/978-981-15-0324-5_28.

[10] NACTO, "NACTO Urban street design guide," 2012.

[11] M. A. MacKeith, "Rubenstein, Harvey M., 'Pedestrian Malls, Streetscapes, and Urban Spaces' (Book Review)," Town Plan. Rev., 1993, doi: 10.3828/tpr.64.4.pl2276734285j2n2. 